\title{
Mechanical Properties for Circumferential Welding Applied to UNS S32750 Super Duplex Stainless Steel Using the GMAW Process with CMT Control
}

\author{
Bruno Pizol Invernizzi, Leandro Gusmão Silva, Maurício David Martins das Neves \\ Nuclear and Energy Research Institute (IPEN), São Paulo University, São Paulo, Brazil \\ Email: brunopizol@gmail.com, leandrogusmão.s@gmail.com, mdneves@ipen.br
}

How to cite this paper: Invernizzi, B.P., Silva, L.G. and das Neves, M.D.M. (2019) Mechanical Properties for Circumferential Welding Applied to UNS S32750 Super Duplex Stainless Steel Using the GMAW Process with CMT Control. Engineering, 11, 576-591.

https://doi.org/10.4236/eng.2019.119040

Received: July 25, 2019

Accepted: September 14, 2019

Published: September 17, 2019

Copyright $\odot 2019$ by author(s) and Scientific Research Publishing Inc. This work is licensed under the Creative Commons Attribution International License (CC BY 4.0).

http://creativecommons.org/licenses/by/4.0/

\section{cc) (i) Open Access}

\begin{abstract}
Super Duplex Stainless Steel has been studied for oil and gas industry applications since the $90 \mathrm{~s}$, but their welding always is a technical issue. Then different methods were developed to meet all requirements presents in ASME standards, where most of are applied for lower production, when compared to other materials such carbon steel. This study accomplished circumferential welding experiments in base material (BM) - UNS S32750 Super Duplex Stainless Steel with a thickness of $3.68 \mathrm{~mm}$. Welding was performed using GMAW (Gas Metal Arc Welding) process with CMT (Cold Metal Transfer) control and the aid of a Motoman robot and a turntable device, which were used to ensure the accurate positioning of the torch and that the welding has been fully implemented in the $1 \mathrm{G}$ position, respectively. This process achieves higher production in relation other welding process usually applied for this material class. The joints which presented adequate dimensional results were, then, subjected to tensile and hardness Vickers tests. To avoid the lack of penetration problem, the welding was performed using the CMT process combined with pulsed arc, thus, resulting in full penetration and improved surface finish. The results have shown that the CMT procedure, combined with pulsed arc, led to an adequate superficial finishing, mechanical properties and corrosion resistance in accomplishment with the requirements presented in applicable standards.
\end{abstract}

\section{Keywords}

GMAW-Welding CMT, Automated Welding, Stainless Steel Super Duplex, Mechanical Properties, Vickershardness 


\section{Introduction}

Stainless steel is a type of metallic material that has mechanical properties and high corrosion resistance, suitable for use in many different segments. It could be applied to various geometries, especially pipes for applications in the chemical and petrochemical industry, as well as in cutlery, civil construction, furniture industry, food industry and hospitals. Currently, stainless steel pipes are used in the manufacture of several types of equipment, such as: condensers, heat exchangers and pipes, with the main support of ASTM A249 [1], ASTM A269 [2], ASTM A270 [3] standards, including ASTM A312 [4], for high temperature corrosive products and ASTM A213 [5], for the use of heat exchangers [6] [7] [8] [9] [10].

New requirements, not only in the nuclear sector but, also, in the oil and gas areas, including Brazilian pre-salt, require materials with improved mechanical properties, which interfere in the mentioned manufacturing processes. Pipeline welding is a manufacturing process that plays a significant role, with its main requirements defined in ASME Section IX and ASME B31.3 [11] [12] [13]. The super duplex steel UNS S 32750 has been applied for this circumstance, because it meets the needs for new alloys with superior mechanical properties and resistance to corrosion, when compared to duplex stainless steels. The increase in tensile strength and hardness, as well as the increased corrosion resistance of this material, could increase the use of UNS S 32750 steel in aggressive environments containing chlorides, such as sea water in tropical (hot) locations, which is the case of pre-salt oil exploration. This material also affords to be used in tertiary systems of nuclear reactors, since this system could use saline water on its cooling system, which may be heated to temperatures above $70^{\circ} \mathrm{C}\left(158^{\circ} \mathrm{F}\right)$ [6] [7] [8]] [9] [10].

The mainly issue for the super duplex steel UNS S 32750 application is the microstructure balance of the phases, in values nears 50:50 of austenite and ferrite, which results in highest corrosion rate when this proportion is not achieved. To avoid this problem and allow high welding productivity, the present work focused on GMAW (Gas Metal Arc Welding) process with CMT (Cold Metal Transfer) control. The results obtained were satisfactory, but the welding reinforcement would be a problem, since this process results in greater welding deposits when compared to TIG welding process, which may lead to a lower fatigue resistance, although the others mechanical properties are improved or, at least, preserved.

\section{Literature Review}

Stainless steel could be classified according to the type of predominant microstructure in ferritic, austenitic, martensitic and duplex. Figure 1 shows the Schaeffler diagram, where the microstructure obtained from these steels depends on the chromium and nickel equivalent. The increase in tensile strength and hardness, as well as the increased corrosion resistance of this material could 


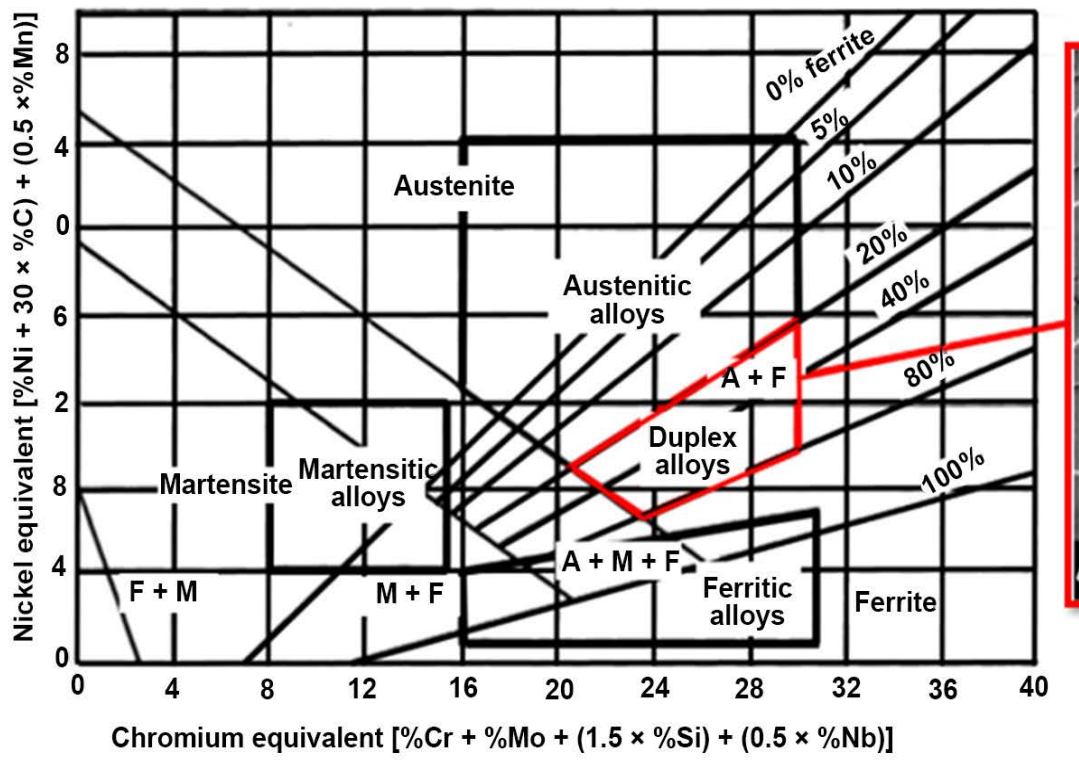

(a)

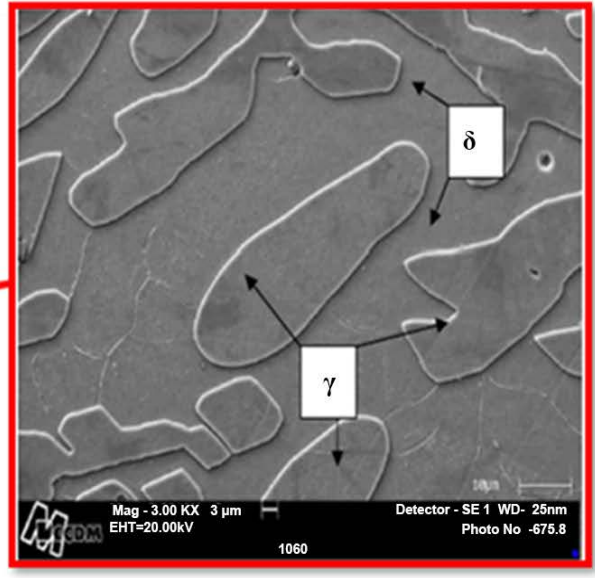

(b)

Figure 1. (a) SCHAEFFLER Diagram (Source: Modified from: ASM Handbook [14]) and (b) Duplex Stainless Steel microstructure shows gamma phase $(\gamma)$ and delta phase $(\delta)$, where the delta phase is the continuous phase and, then, it is the matrix (Source Martins [15]).

increase the use of UNS S 32750 steel in aggressive environments containing chlorides, such as sea water in tropical (hot) locations, what is the case of pre-salt oil exploration. This material also affords to be used in tertiary systems of nuclear reactors, since this system could use saline water on its cooling system, which may be heated to temperatures above $70^{\circ} \mathrm{C}\left(158^{\circ} \mathrm{F}\right)$ [6] [7] [8] [9] [10].

The microstructure of a duplex stainless steel is composed of a mixture of austenite and ferrite, presenting approximately $50 \%$ of each phase characterized by having a ferritic matrix structure with austenite islands, homogeneously distributed. UNS S32750 is a type of stainless steel with higher alloying element additions that provides greater mechanical and pitting corrosion resistance. UNS S32750 has been developed with the objective to be applied in environments containing chlorides and with temperatures superior to those used for common duplex alloys [6] [7] [8] [9] [10].

The 50:50\% ratio between the ferritic and austenitic phases contributes to the high performance of the structure. Therefore, any processing involving heating and cooling out of balance, like in welding, could change the phase balance and modify various properties. During welding, precautions should be taken, such as to avoid the preferential diffusion of the alloying elements to a phase and to hinder the formation of precipitated phases. The kinetics of precipitation of the intermetallic phases and their influence on the corrosion resistance depends on the present chemical composition of the region, so each alloy should be studied to know the effect of welding on the microstructure and properties [14]-[20]. 
The welding applied to super duplex steel has the difficulty of maintaining the balance between austenite (50\%) and ferrite (50\%) phases, besides the possibility of forming undesirable intermetallic phases, such as the sigma $(\sigma)$ and chi $(\chi)$ phases, as well as the appearance of $\mathrm{Cr}_{2} \mathrm{~N}$, since these steels have high percentages of nitrogen. As observed by Tavares [16], to obtain a correctly balanced microstructure and without the presence of intermetallic phases, the heat imposed during the welding operation should be between 500 and $2000 \mathrm{~J} / \mathrm{mm}$ and may be determined using the Equation (1),

$$
\boldsymbol{H}=(\boldsymbol{\eta} \cdot \boldsymbol{I} \cdot \boldsymbol{V}) / \boldsymbol{v}
$$

where: $H$-heat input, $\eta$-thermal efficiency, $I$-welding current, $V$-welding voltage, $v$ - travel speed.

According to literature information [17], welding performed in this material should be accomplished with an Argon-based protection gas (Ar) with 2\% to 3\% of $\mathrm{N}_{2}$, to supply the nitrogen losses of the AM and ZTA during the process. Nitrogen helps in the formation of the austenite phase, which is a critical point in the welding of duplex and super duplex steel. The cooling rate has a major influence and must be controlled as it impacts the ferrite content. Ferrite content is important for controlling the formation of precipitates.

There is a variation of the MIG/MAG welding process with $\mathrm{CMT}^{\circledast}$ control, which uses transfer of addition material (AM) by pulsed arc and short circuit. The $\mathrm{CMT}^{\circledast}$ patent holder has modified the electrode feed system by inserting two systems for its handling and movement. In this process, after the welding touches the part and generates a short circuit, the pull system present in the torch performs the return of the addition material and, when it reaches the maximum position of the arc length, the equipment abruptly increases the current, generating a pulse of sufficient magnitude to release droplets by spray process. It is noted that a short circuit occurs with the drop touching the surface of the $M B$, after the short circuit, the retraction of the addition material (wire) occurs, and when the arc is at its greatest length, a current peak happens with the detachment of the "drop", which is transferred by spray to the base metal.

According to Timothy [21], GMAW welding with the $\mathrm{CMT}^{\varpi}$ device enables low heat input into the joint. In the $\mathrm{CMT}^{\circledast}$ process, the detachment of the addition material (electrode) tip occurs without the use of an electric pulse, but by the retreat of the welding electrode, associated with the modification of the waveform of the welding current determined by the electronic control of the source, making the movement of the electrode possible. The first system is in the wire feeder, as it is observed in conventional equipment. The second system is inside the torch, which is responsible for the oscillation movement back and forth of the wire, by means of an alternating current servo motor. This oscillation movement may be performed up to 90 times per second. In addition, the process has a buffer between the two systems, which is allocated in the torch cable, working as a type of wire compensator, absorbing backward movement and avoiding stress during this electrode feeding motion. 
The objective of this study is to investigate the behavior of tubular joints of the UNS S32750 super duplex stainless steel welded by the GMAW (Gas Metal Arc Welding) process and using the $\mathrm{CMT}^{\oplus}$ (Cold Metal Transfer) control, through: tensile, Vickers hardness, microstructural characterization and corrosion resistance tests.

\section{Materials and Methods}

This study was performed using as base metal a Super Duplex UNS S32750 steel pipe with $48.20 \mathrm{~mm}$ outside diameter and $3.68 \mathrm{~mm}$ thickness, supplied by Sandvik Materials Technology do Brasil SA. The addition material (AM) used to perform the welding was AWS A5.9 of classification ER2594, supplied by Voestalpine Bohler Welding Soldas do Brasil Ltda. The protective gas used during the welding was the Argon mixture containing 2.5\% Nitrogen and the purge gas for the root was the pure Argon. In Table 1, the chemical composition for both materials used is showed, BM and AM respectively.

This study was carried out using tubes with $75 \mathrm{~mm}$ length, which had its bevel machined to $25^{\circ}$ with $1 \mathrm{~mm}$ of bevel nose. GMAW welding using CMT control was performed with a turntable device and a 6-axis Motoman robot, with DX100 controller. In Figure 2, these devices are showed. The welding equipment used was a Fronius Trans Pulse Synergic 5000 CMT, with current capacity of 360A at $100 \%$. The following parameters were pre-set, protection gas flow (12 liters/minute), purge gas flow (12 liters/minute), root opening $(1.5 \mathrm{~mm})$, stick-out $(15 \mathrm{~mm})$ and weld speed $(8.75 \mathrm{~mm} / \mathrm{sec})$. The CMT process was used in combination with pulsed arc, which allowed higher weld penetrations to be obtained.

The welding was performed using the usual CMT program for welding electrode ER2594, so all results obtained depends on this program, which is related to the welding wire characteristics, it's diameter and the welding feed speed (WFS). For each kind of welding wire and it's diameter, Fronius has developed a specific synergic curve, which already brings the correct current and voltage to be used for each WFS. The command that could be load for the operator is the WFS, but the voltage could be moved up or down using the command arc length $\mathrm{AL}$, which came from arc length used in the welding. The AL command is based on Fronius established curve for voltage, where this parameter could be changed from $-30 \%$ to $+30 \%$. So, if the curve for a specific material gives a voltage of 20 $\mathrm{V}$, for example, if it's used a $+10 \% \mathrm{AL}$, so the final voltage would be $22 \mathrm{~V}$, but the current is kept on the curve specification. During the process execution the voltage

Table 1. Chemical composition in mass for UNS S32750 (BM) and AWS A5.9 ER2594 (AM).

\begin{tabular}{cccccccccccc}
\hline & $\mathrm{C}$ & $\mathrm{Si}$ & $\mathrm{Mn}$ & $\mathrm{P}$ & $\mathrm{S}$ & $\mathrm{Cr}$ & $\mathrm{Ni}$ & $\mathrm{Mo}$ & $\mathrm{W}$ & $\mathrm{Cu}$ & $\mathrm{N}$ \\
\hline $\begin{array}{c}\text { UNS S32750 } \\
\text { AWS A5.9 }\end{array}$ & $\leq 0.03$ & $\leq 0.80$ & $\leq 1.20$ & $\leq 0.02$ & $\leq 0.01$ & 25.00 & 7.00 & 4.00 & - & - & 0.30 \\
$\begin{array}{c}\text { ER2594 } \\
\text { ER2 }\end{array}$ & 0.40 & 0.90 & 0.02 & $<0.01$ & 25.60 & 9.30 & 3.90 & 0.40 & 0.50 & 0.24 \\
\hline
\end{tabular}




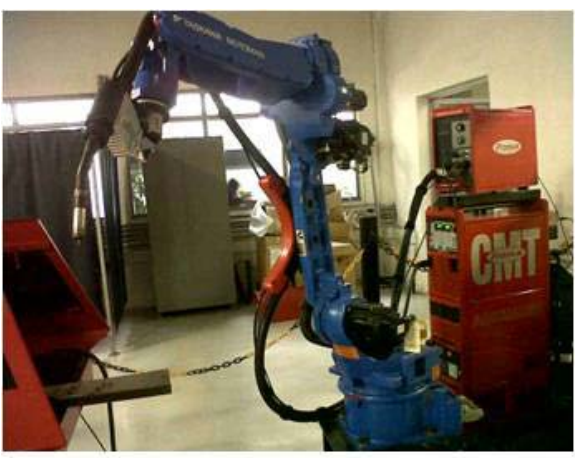

(a)

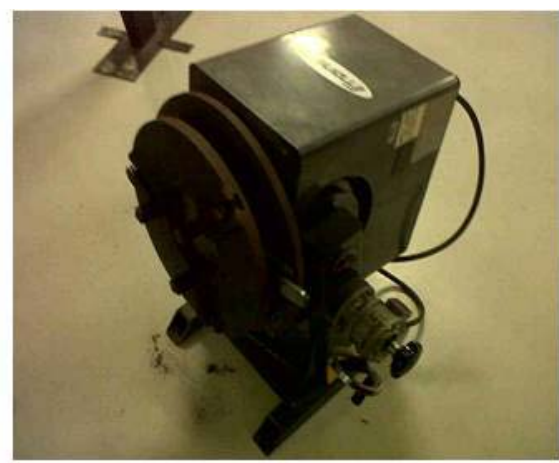

(b)

Figure 2. Welding devices: (a) MIG Welding equipment; (b) Turntable equipment.

chooses by the operator would change to keep the arc welding open and stable, so not necessarily it would be the same selected by the operator. Fronius Brazil didn't have the correct curve applied for the used argon nitrogen mixture gas. There was no curve in the equipment for mixing argon nitrogen gas, so the pure argon curve was used during these welds, which has proved, during the welding execution, to be allowed to provide correct welding parameters, resulting in an acceptable welding joint.

Twelve tests were performed with WFS (Wire Feed Speed) ranging from 250 to $700 \mathrm{~cm} /$ minute to achieve full penetration, which was achieved only for 700 $\mathrm{cm} /$ minute WFS. For the other parameters ranging from $250 \mathrm{~cm} /$ minute and 650 $\mathrm{cm} /$ minute, it was not possible to obtain total penetration or to stabilize the electric arc along welded joints for welds with WFS less than $600 \mathrm{~cm} /$ minute. For $700 \mathrm{~cm} /$ minute WFS, three different tests were performed varying the arc length (AL) of $-5 \%, 0 \%$ and $+5 \%$. The specimens produced for this last condition $(700$ $\mathrm{cm} /$ minute), for all arc length, were approved in the visual test, since among all the applied parameters only these resulted in full penetration. However, just these last conditions were subjected to tensile, Vickers microhardness and corrosion tests. The metallography for phase quantification was performed by EDS, in the samples with speed $700 \mathrm{~cm} /$ minute or over.

Samples welded were measured and submitted to microstructural evaluation with ferrite and austenite quantification, using an Olympus BX-43 microscope with coupled camera and Zeiss software. The samples were prepared by sanding and polishing followed by immersion in Behara reagent containing $50 \mathrm{ml}$ of $\mathrm{HCl}, 50 \mathrm{ml}$ of water. Then, to evaluate the presence of detrimental phases, the "A" practice was performed, which consists of a sodium hydroxide solution etch test using a source of direct current, where the sample was placed in the solution as the anode, while a platinum electrode was placed in the solution as the cathode. The solution was prepared by adding $40 \mathrm{~g}$ of reagent grade sodium hydroxide $(\mathrm{NaOH})$ to $100 \mathrm{~g}$ of distilled water. Before the analysis, the samples were polished to allow an increase of $400 \times$ using optical microscope. After etching, the samples were rinsed in hot water and in alcohol, followed by air drying. 
An acid solution containing, approximately, $6 \% \mathrm{FeCl}_{3}$ weight was prepared to perform the corrosion test. The solution preparation was carried out as described in the standard ASTM A923 [18], using $100 \mathrm{~g}$ of $\mathrm{FeCl}_{3} \cdot 6 \mathrm{H}_{2} \mathrm{O}$ dissolved in $900 \mathrm{ml}$ of reagent. The assay was performed at $\left(40^{\circ} \mathrm{C} \pm 2^{\circ} \mathrm{C}\right)$ temperature, maintained by an Ethik Techology AGI.114.1001 heating plate, for a period of 96 hours. The samples were cut to $15 \mathrm{~mm}$ width and length, approximately, half of the tube perimeter, the imperfections of the face and root removed. The results obtained in the corrosion tests were used to calculate the corrosion rate, as described by practice "C" in ASTM A923 [18]. This practice describes testing for UNS S32750 material should be performed at a temperature of $40^{\circ} \mathrm{C}$, where mass loss should be less than or equal to $10 \mathrm{mdd}\left(\mathrm{mg} / \mathrm{dm}^{2} \times\right.$ days). The corrosion rate calculation, according to ASTM A923 [18], is performed as presented in Equation (2).

$$
\text { Corrosion rate }(\text { mdd })=\frac{\text { weight loss }(\mathbf{m g})}{\text { surface area }\left(\mathrm{dm}^{2}\right) \times \operatorname{time}(\text { days })}
$$

Vickers hardness samples were prepared according to ASTM E384 [19]. This test was performed using a Duravision Vickers model 70 microhardness equipment. Eleven Vickers hardness points were made for each sample, using the weld metal (WM) center as starting point, passing through the heat affect zone (HAZ) and the BM.

The tensile specimens were machined according to ASME IX standard [12], as shown in Figure 3. The test was performed using a universal testing machine on Kratos model K30,000, equipped with a load cell for up to 30 tons and test speed of $15 \mathrm{~mm} / \mathrm{s}$.

\section{Results and Discussion}

Welding conditions used are shown in Table 2, as well as the results obtained for the welding current, the welding voltage and the heat input. In this table, it is noticed that the increase of WFS and arc length (AL) result in increase of the welding current, the welding voltage and, consequently, the heat input.

The correlation between WFS, current and voltage is stablished by Fronius synergic curve, and the WFS is chosen by the operator. It's possible to note that, for the conditions evaluated in this work, the current and the voltage increases with WFS increase, so the heat input increases too. When the AL was variated, only the voltage presents pronounced variations, where it's possible to note that both increased together, resulting in heat input increases, while the current was maintained almost the same, presenting a derisory variation. The parameter $\mathrm{AL}$ didn't promote any change in current, which is a specificity from this process, and the current keeps on its synergic curve specification.

Table 3 shows the results obtained for the Vickers microhardness and tensile tests, both for the welding conditions that showed full penetration and for the base metal. In this table, it is noticed that the heat input influence on the results obtained for the mechanical tests is very low, and it is not possible to establish a 


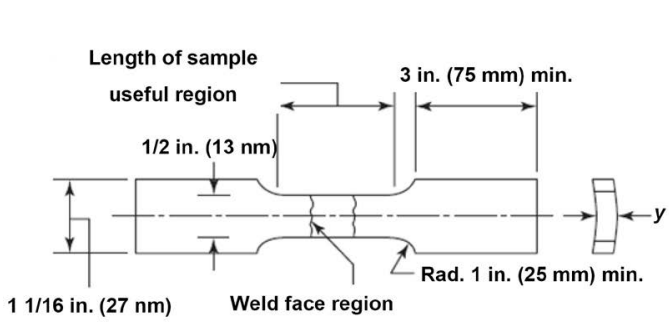

(a)

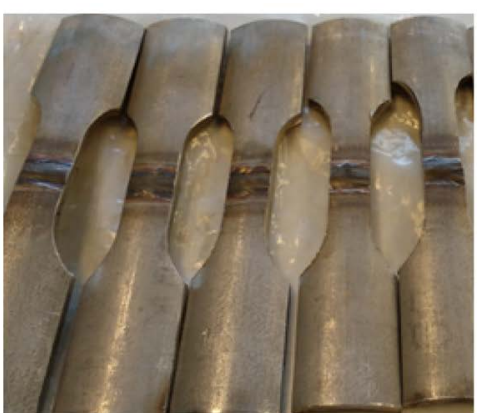

(b)

Figure 3. (a) ASME IX sub size tensile test specimens and (b) Sub size samples machined for tensile test, according to ASME IX.

Table 2. Results obtained for welding using the CMT process combined with pulsed arc.

\begin{tabular}{cccccc}
\hline Condition & AL (\%) & WFS (cm/min) & Current (A) & Voltage (V) & Heat input $(\mathrm{J} / \mathrm{mm})$ \\
\hline 1 & -5 & 600 & 134 & 19.2 & 294 \\
2 & -5 & 650 & 148 & 20.3 & 343 \\
3 & -5 & 700 & 160 & 21.5 & 394 \\
4 & 0 & 700 & 164 & 22.3 & 418 \\
5 & +5 & 700 & 163 & 23.7 & 442 \\
\hline
\end{tabular}

Table 3. Mean values of the results obtained for the tensile strength and Vickers hardness tests in relation to the heat input.

\begin{tabular}{cccc}
\hline Condition & Heat input $(\mathrm{J} / \mathrm{mm})$ & Vickers microhardness (HV0.5) & Tensile strength (MPa) \\
\hline Specified $^{1}$ & - & $<318$ & $>800$ \\
1 & 294 & - & - \\
2 & 343 & - & - \\
3 & 394 & $285 \pm 7.87$ & $866 \pm 9.20$ \\
4 & 418 & $290 \pm 6.96$ & $868 \pm 16.80$ \\
5 & 442 & $288 \pm 6.40$ & $863 \pm 23.10$ \\
Base Metal & - & $292 \pm 4.89$ & $872 \pm 5.70$ \\
\hline
\end{tabular}

${ }^{1}$ According ASTM A789/A789M-18, Standard Specification for Seamless and Welded Ferritic/Austenitic Stainless Steel Tubing for General Service.

behavior pattern. Roldão [20] conducted a study using duplex steels, where he observed that the heat input, although influencing the phase balance, has no influence on the mechanical properties. The results obtained for the tensile strength and Vickers microhardness tests are according to the specification for all conditions, although the results are lower than base metal, they are all approved according to ASME IX [12], based on the specification and not comparing with the base metal results, even though all results are very close. Thereafter, all results are according to Roldão [20] conclusions, namely, it is not possible to determine a behavior pattern between mechanical results and heat input, at least for all con- 
ditions tested in this article.

Figure 4 shows the fracture surface aspect after tensile test applied for condition 3. The aspect for all three tested conditions was similar. It is possible to see dimples and plastic deformation on the surface of the whole region analyzed; these characteristics are of ductile fracture.

In Figure 5(a) the surface of the welding bead is observed. From visual inspection were not noted for the presence of discontinuities such as porosity, cracks, undercut and underfill. Figure 5(b) shows the samples after machining, for removing the reinforcement and cleaning the weld bead to make surfaces look smooth and polished to avoid the presence of preferential corrosion regions. Figure 6 shows the devices and appearance of the aqueous solution of the corrosion test.

Table 4 shows the results obtained for the phase quantification of conditions 1 to 5 and the base metal, as well as the results obtained for the corrosion tests applied according to practice "C", present in ASTM A923 [18].

A behavioral pattern between corrosion loss and austenite percentage has been identified and is illustrated in Figure 7. In this situation, it can be observed that the increase of heat input led to higher percentages of austenite, behavior observed for WM and ZTA.

Figure 8(a) and Figure 8(b) show the interfaces between the weld bead and the base metal. A dendritic morphology is observed in the weld metal caused by a high speed of solidification. In the HAZ region, a smaller amount of austenite and higher ferrite than in weld metal and base metal are observed. The MB presented typical mechanically worked structure with a thinner and elongated grain aspect. These effects are confirmed in Table 4, where it is possible to see that, for all conditions, HAZ has less percentage of austenite than the WM, this effect could be explained by the nitrogen losses and rapid cooling that occur during and after welding.

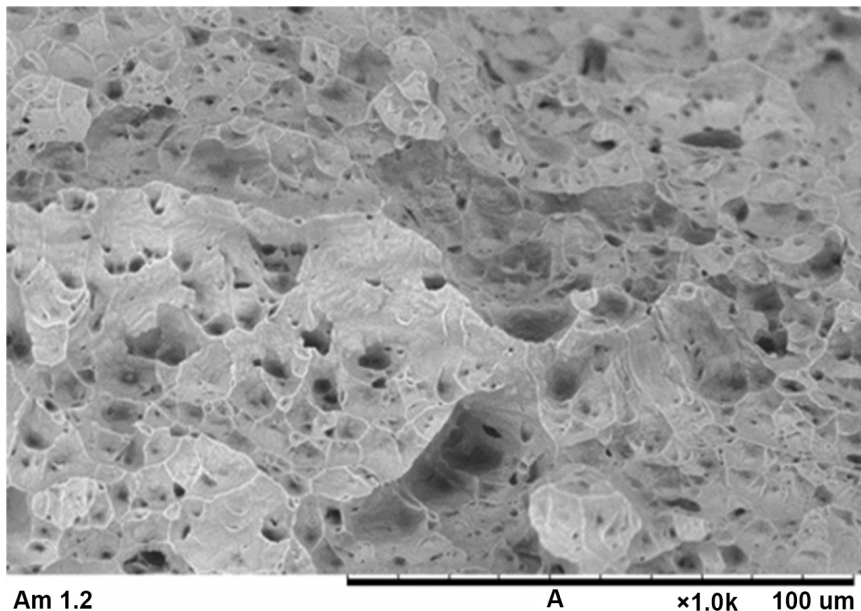

(a)

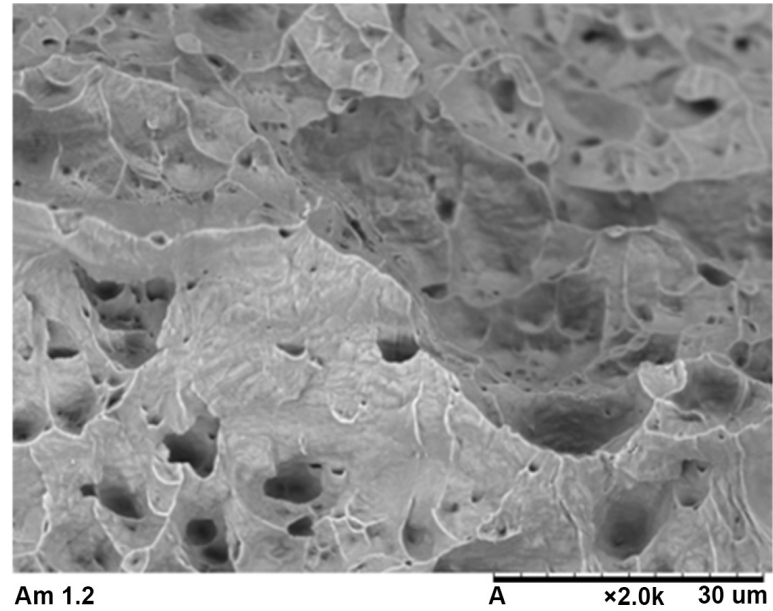

(b)

Figure 4. (a) and (b) Fracture surface aspect after tensile test applied. 


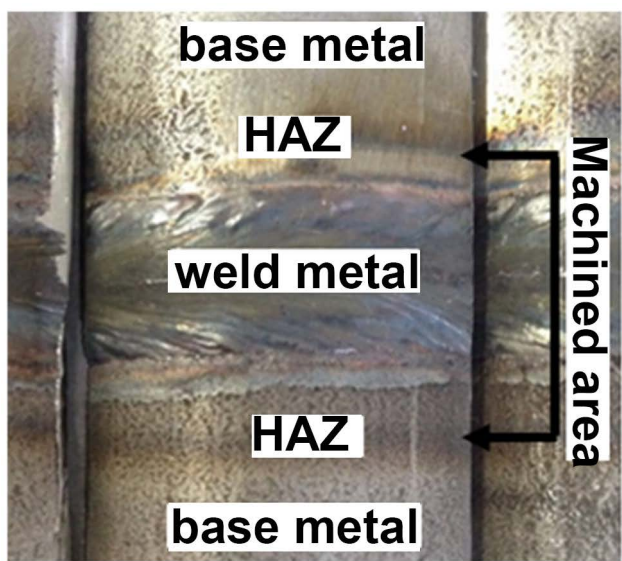

(a)

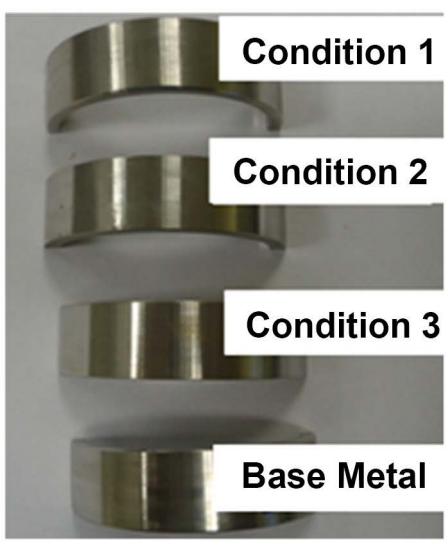

(b)

Figure 5. Samples applied for corrosion tests (a) Welded region before machining, showing the machining area, and (b) Machined samples used for corrosion test.

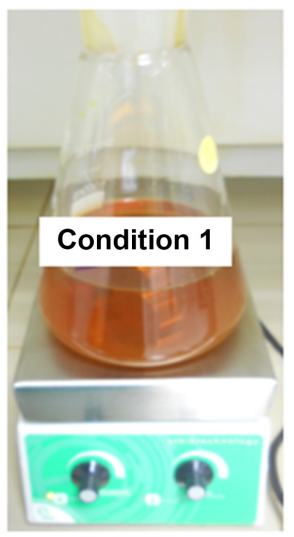

(a)

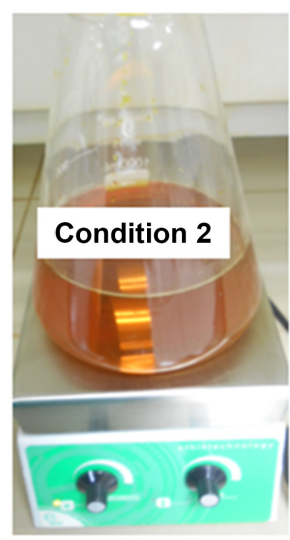

(b)

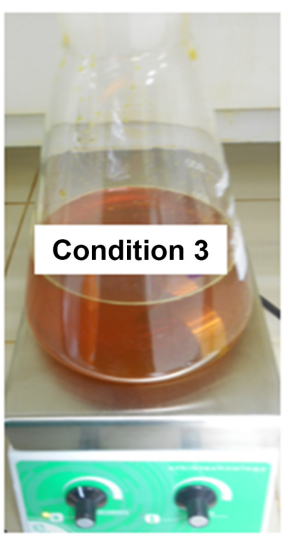

(c)

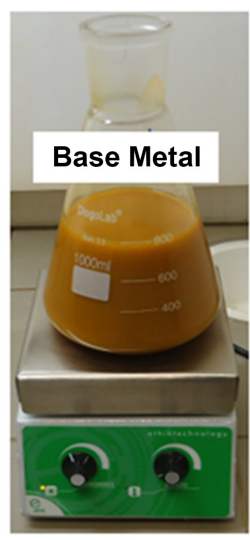

(d)

Figure 6. Corrosion test being performed (a) Condition 1; (b) Condition 2; (c) Condition 3; (d) Base metal.

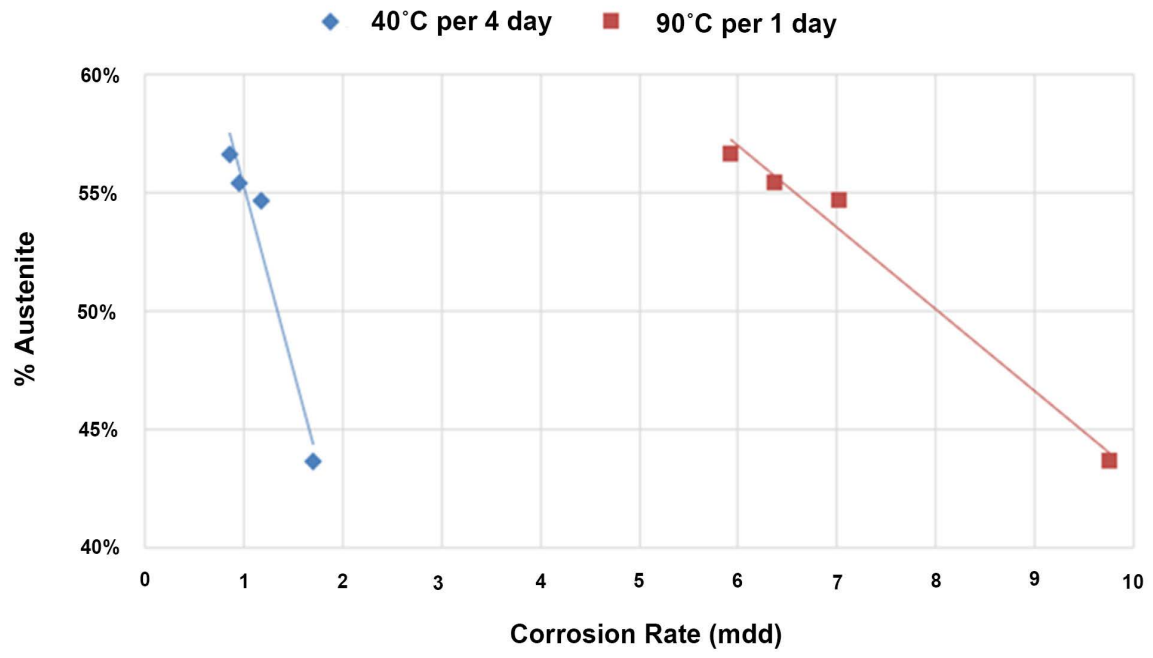

Figure 7. Results obtained for corrosion tests at $40^{\circ} \mathrm{C}$ and $90^{\circ} \mathrm{C}$. 


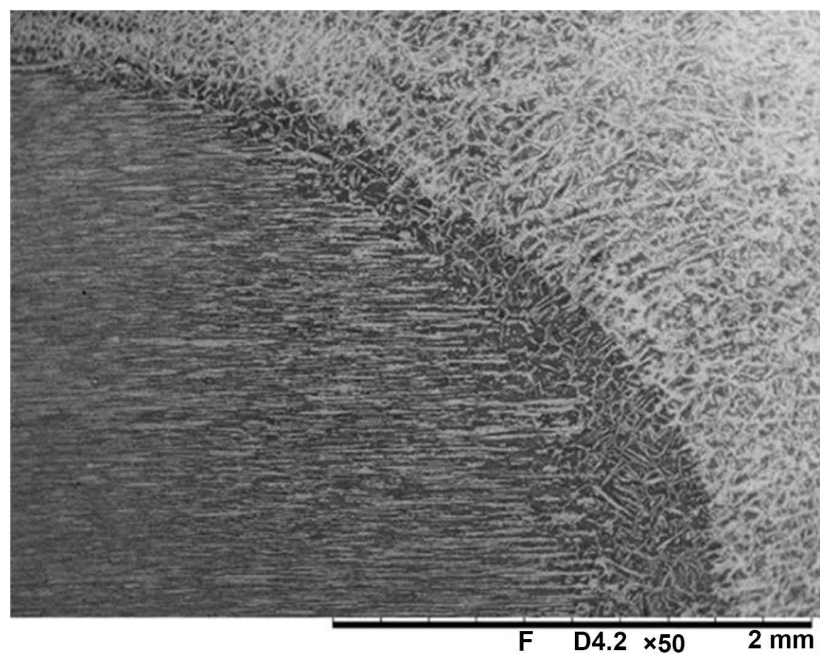

(a)

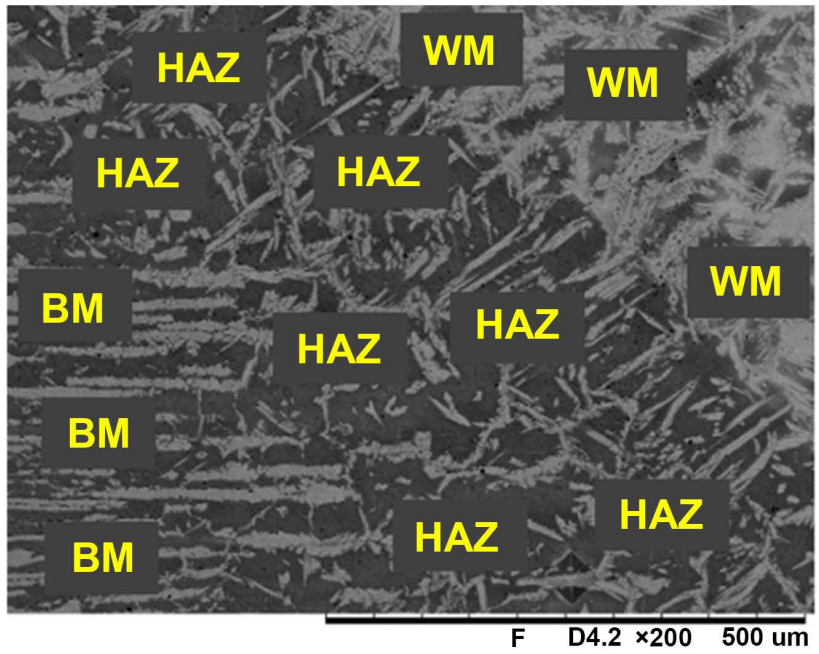

(b)

Figure 8. Results obtained for MEV analyzes (a) and (b) WM interface with HAZ and BM interface with HAZ.

Table 4. Austenite percentage and corrosion rate obtained for BM, HAZ andWM.

\begin{tabular}{cccccc}
\hline Condition & $\begin{array}{c}\text { Heat input } \\
(\mathrm{J} / \mathrm{mm})\end{array}$ & $\begin{array}{c}\text { HAZ } \\
\text { (\% Austenite) }\end{array}$ & $\begin{array}{c}\text { WM } \\
\text { (\% Austenite) }\end{array}$ & $\begin{array}{c}\text { Corrosion rate } \\
40^{\circ} \mathrm{C}(\mathrm{mdd})\end{array}$ & $\begin{array}{c}\text { Corrosion rate } \\
90^{\circ} \mathrm{C}(\mathrm{mdd})\end{array}$ \\
\hline Specified & - & $30 \%$ to $70 \%^{1}$ & $30 \%$ to $70 \%^{1}$ & $\leq 10^{2}$ & $\leq 10^{2}$ \\
\hline 1 & 294 & $32.78 \% \pm 4.09 \%$ & $41.76 \% \pm 6.23 \%$ & - & - \\
2 & 343 & $31.46 \% \pm 3.98 \%$ & $48.27 \% \pm 4.56 \%$ & - & - \\
3 & 394 & $34.27 \% \pm 3.17 \%$ & $54.66 \% \pm 3.15 \%$ & 1.17 & 7.03 \\
4 & 418 & $36.33 \% \pm 2.52 \%$ & $55.41 \% \pm 4.39 \%$ & 0.95 & 6.38 \\
5 & 442 & $39.53 \% \pm 4.12 \%$ & $56.65 \% \pm 2.91 \%$ & 0.85 & 5.93 \\
BM & - & $43.63 \% \pm 2.78$ & 1.70 & 9.76 \\
\hline
\end{tabular}

${ }^{1}$ According to NORSOK M-601:2016-Welding and Inspection of Piping; ${ }^{2}$ According to ASTM A923 [18].

In the comparison of the corrosion rates, it could be observed that the results obtained in the temperature of $90^{\circ} \mathrm{C}$ were higher than the $40^{\circ} \mathrm{C}$ for the analyzed welding conditions. When analyzed at the same temperature, it is verified that the corrosion rates decreased with the increase of austenite percentage, even when compared to the base metal. The base metal used has a lower austenite percentage than the molten zone. No pitting corrosion point was observed in the evaluated samples, including WM, HAZ and BM regions. All results for both requirements, austenite percentage and corrosion tests performed at $40^{\circ} \mathrm{C}$ and $90^{\circ} \mathrm{C}$ are in accordance with the standard limits, which are included in Table 4 as "Specified", so all weld conditions are approved.

Figure 9 shows the analysis performed by energy dispersive X-ray spectroscopy (EDS) on a horizontal line of a standard sample, considering the line going through continuous and discontinuous phases. Note that all elements analyzed had similar results for the regions with continuous and non-continuous phases. 


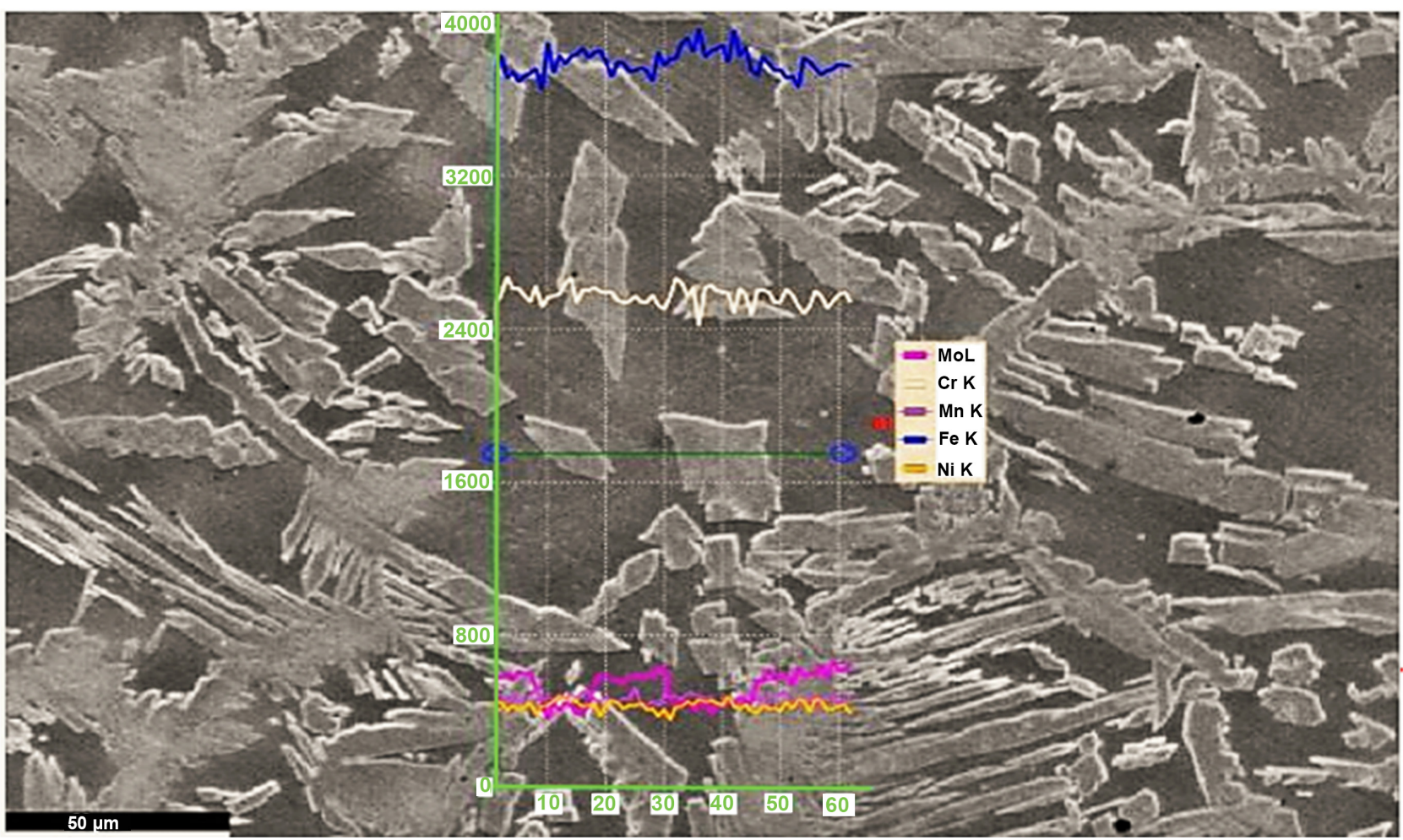

Figure 9. EDS analyze line applied to HAZ.

Although the EDS analysis is considered semi-quantitative, there was a tendency for higher $\mathrm{Cr}$ and Mo contents in the continuous phase, while the measurements made for $\mathrm{Ni}$ indicated that the highest contents were in the discontinuous phase, in relation to the continuous phase. Studies performed [15] [16] [20] [21] [22] [23] indicate that molybdenum and chromium are stabilizers of ferrite, while nickel is stabilizer of austenite. In the case of UNS S 32750 steel, the continuous phase is delta ferrite and the discontinuous phase is composed of austenite islands.

In Figure 10, a comparison between the WM, HAZ and BM structures is presented. Figure 10(a) shows that HAZ has lower austenite content than WM. This result is in accordance with the obtained values presented in Table 4. A comparison between HAZ and WM, such as Figure 10(b) and Figure 10(c), is difficult, because their structures are different, so a direct comparison could leave to an incorrect interpretation. The same rule applies to WM and BM. Table 4 shows that WM has more austenite than base metal, which would be explained due to the protective atmosphere with the presence of nitrogen in its chemical composition. Also, during the welding, the nitrogen contained in HAZ could diffuse and dissolve in WM, once the liquid phase has greater nitrogen solubility than the solid phase [22]. Then, when WM solidifies, it has a greater nitrogen quantity that leads this phase to a greater nitrogen percentage than HAZ and base metal. The nitrogen is a stabilizer of austenite, so when WM solidifies, it has a greater nitrogen quantity resulting in greater austenite quantity 


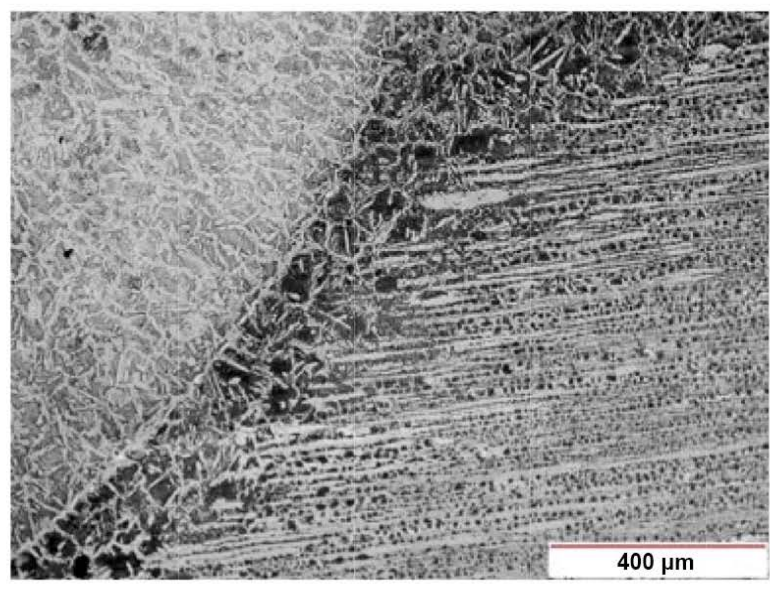

(a)

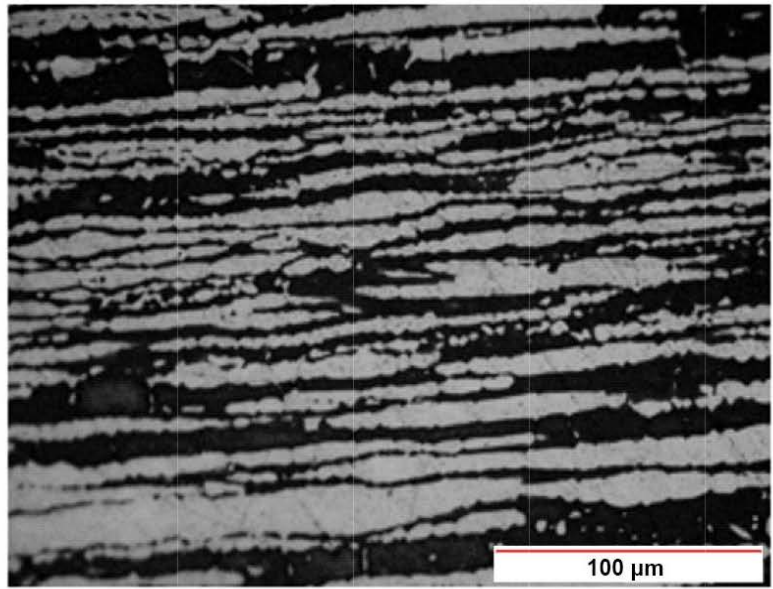

(c)

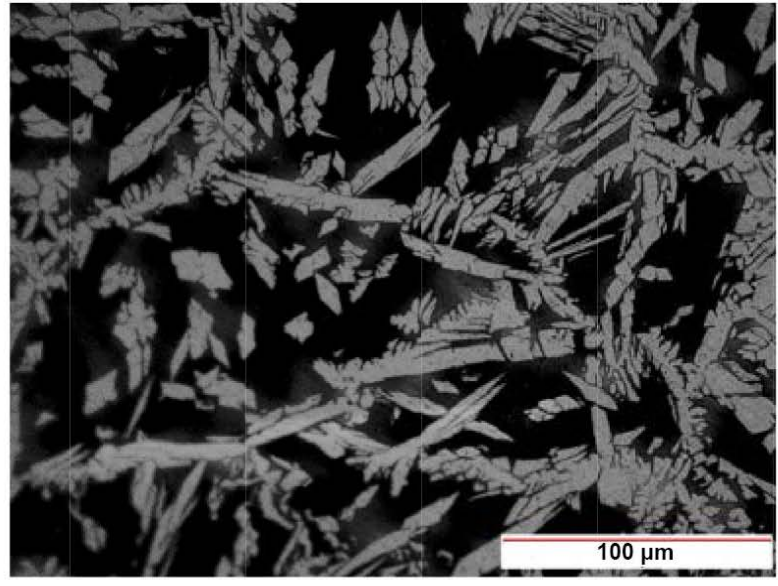

(b)

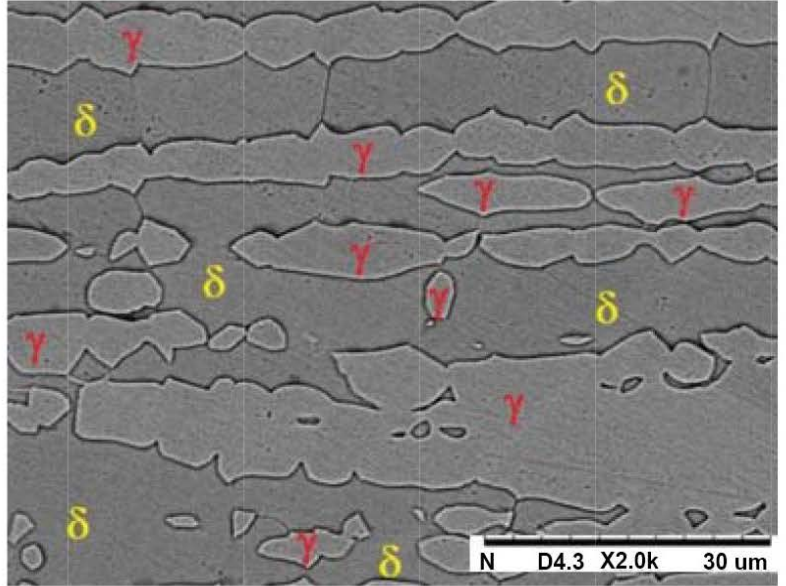

(d)

Figure 10. Welding zones, (a)WM-HAZ-WM interfaces; (b) HAZ; (c) and (d) WM with continuous ( $\delta$ ferrite) and discontinuous ( $\gamma$ austenite) phase identification.

[14]. In Figure 10(c) and Figure 10(d), corresponding to BM, a microstructure aligned by the mechanical conformation process formed by a continuous $\delta$ ferrite phase and a discontinuous $\gamma$ austenite phase is observed.

Figures 11(a)-(f) show the images obtained by optical microscopy after tests based on the ASTM A923 standard. In these images, the presence of deleterious intermetallic phases was not observed. Only the delta ferrite and austenite phases were detected under these conditions of analysis.

\section{Conclusion}

The heat input under the used conditions did not influence the mechanical properties of the welded joint. The use of a heat input below that specified in the literature, minimum of $500 \mathrm{~J} / \mathrm{mm}$, allowed austenite percentages close to $60 \%$ to be obtained. Even in ZAC it was possible to achieve results above $30 \%$, which is the minimum acceptable value for standards. The increase of heat input caused 


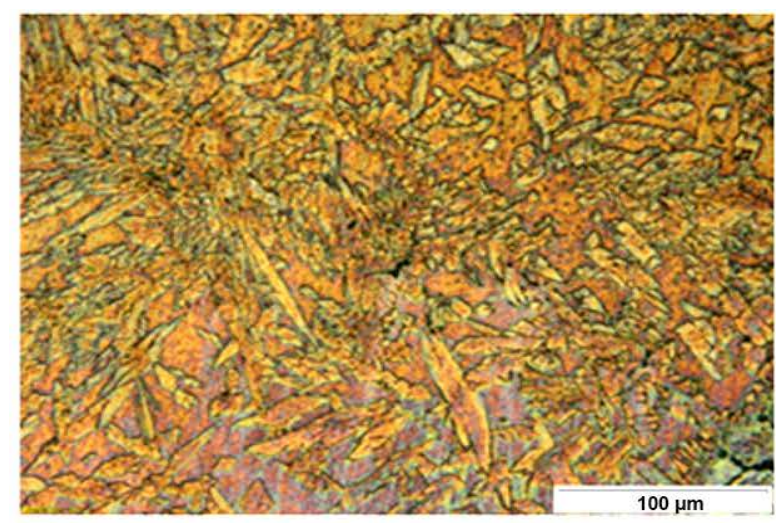

(a)

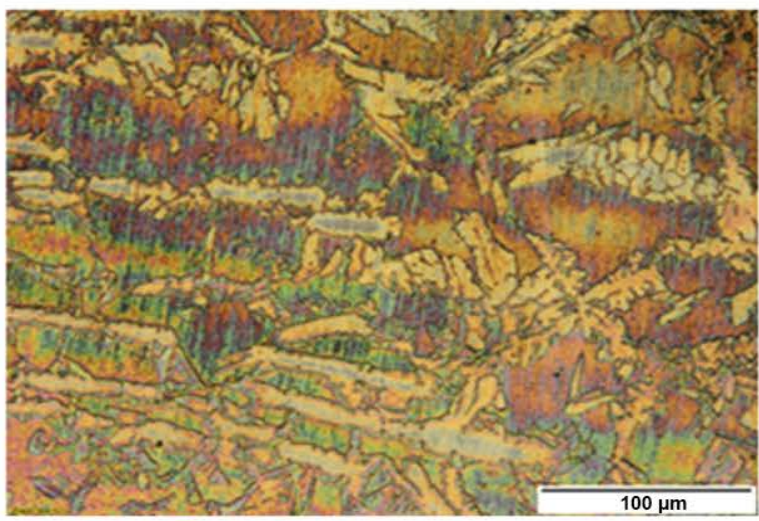

(c)

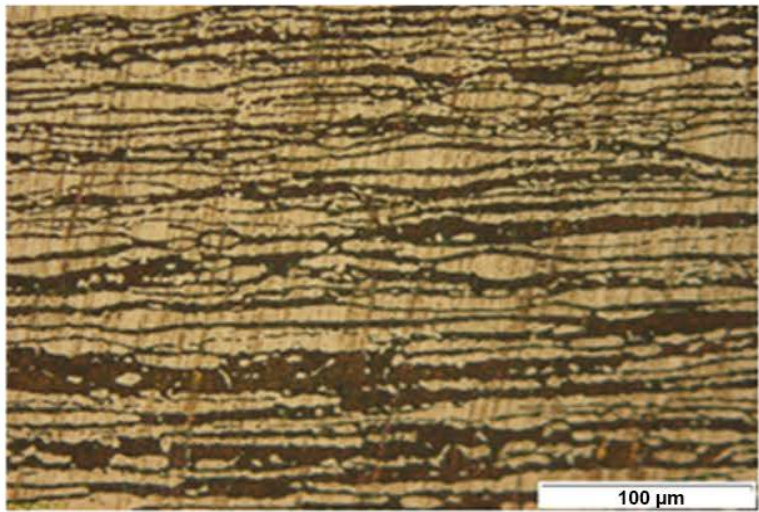

(e)

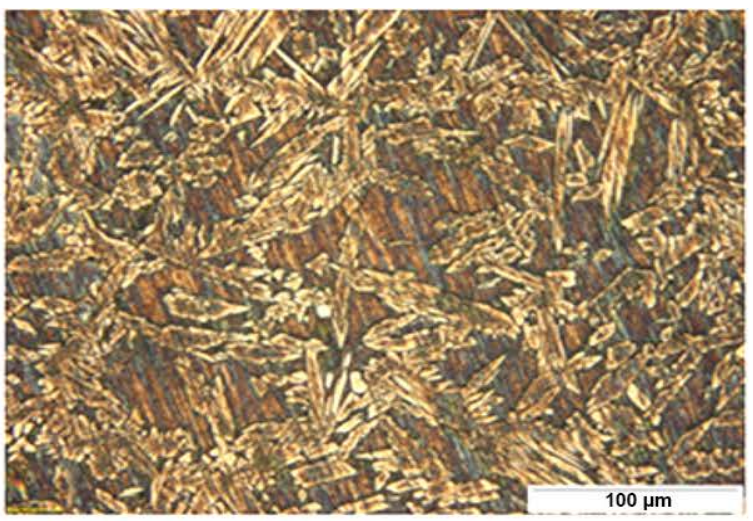

(b)

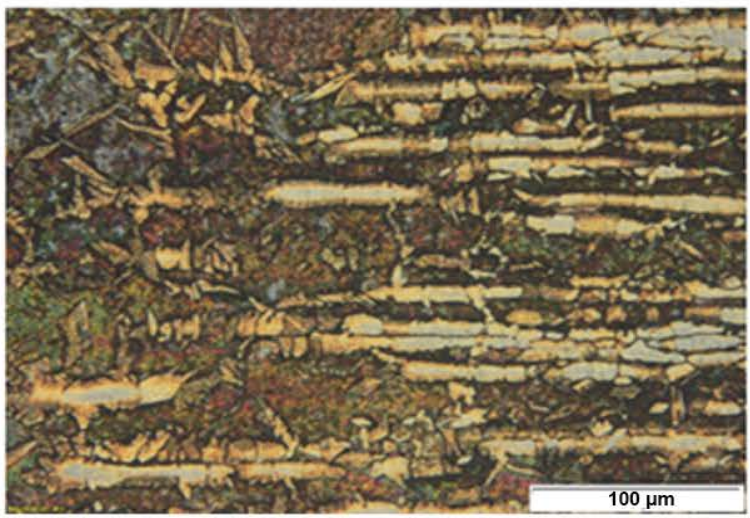

(d)

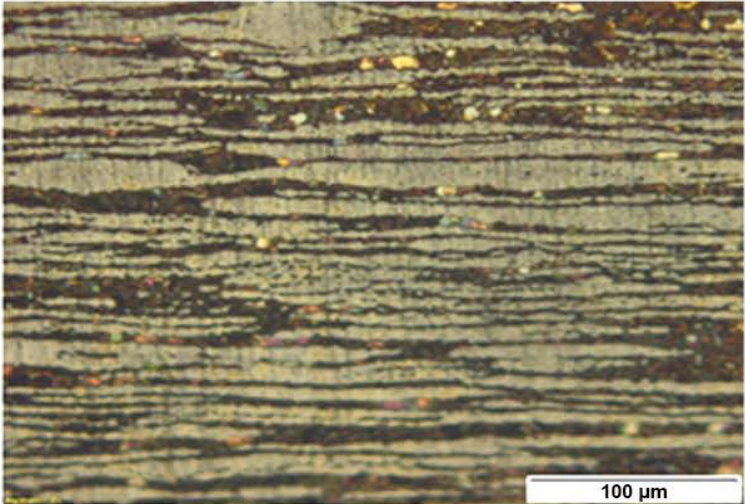

(f)

Figure 11. Results obtained for detrimental phase evaluation as ASTM A923 in condition 3: (a) and (b) WM; (c) and (d) HAZ; (e) and (f) BM.

an increase of austenite percentage. The use of nitrogen gas in the protective atmosphere did not cause the presence of nitrides in the analyzed conditions. The maximum material loss was less than $10 \mathrm{mdd}$. Conditions 3 and 5 used in this work were able to produce full penetration weld and are approved by criteria defined in petroleum standards. Although this work has shown that mechanical properties, such as hardness and tensile strength, meet the standards requirement presents in ASME, it was not possible to the impact and the fatigue resis- 
tance tests, which would represent an opportunity for future researches.

\section{Acknowledgements}

This paper was produced using IPEN (Instituto de Pesquisas Energéticas e Nucleares), Fornius Brasil and Falcão Bauer facilities and resources, besides Sandvik Brasil and Voestalpine Bohler Welding Brasil materials. The process CMT (Cold Metal Transfer) is a controlled GMAW process which belongs to Fronius.

\section{Conflicts of Interest}

The authors declare no conflicts of interest regarding the publication of this paper.

\section{References}

[1] ASTM A249 (2008) Heat Exchanger and Condenser Tubes. American Society for Testing and Materials.

[2] ASTM A269 (2008) Stainless Steel Mechanical Tubes Welded Stainless Steel Boiler Superheater. American Society for Testing and Materials.

[3] ASTM A270 (2003) Sanitary Stainless-Steel Pipe. American Society for Testing and Materials.

[4] ASTM A312 (2008) Standard Specification for Seamless, Welded, and Heavily Cold Worked Austenitic Stainless-Steel Pipes. American Society for Testing and Materials.

[5] ASTM A213 (2008) Standard Specification for Seamless Ferritic and Austenitic Alloy-Steel Boiler, Superheater, and Heat-Exchanger Tubes.

[6] http://brasil.aperam.com/produtos/aco-inox/inox-na-industria/

[7] http://www.abinox.org.br/

[8] http://www.mgrepresentacoes.com.br/

[9] http://www.villaresmetals.com.br/villares/pt/Produtos/Acos-Inoxidaveis/Duplex-eSuper-Duplex

[10] http://www.brownmac.com/

[11] ASME (2009) ASME Secção BPE Bioprocessing Equipment.

[12] ASME (2007) ASME Secção IX ASME Boiler \& Pressure Vessel Code.

[13] Revision, R. (2012) ASME B31.3 Process Piping Guide.

[14] Vander Voort, G.F. (1998) ASM Handbook Vol. 9: Metallography and Microstructures. ASM International, Geauga County, $\mathrm{OH}$.

[15] Martins, M. and Casteletti, L.C. (2005) Caracterização microestrutural do aço inoxidável super duplex ASTM a 890 Grau 6A. 12 CONAF-Congresso de fundição, de 27 a 30 de Setembro de, São Paulo.

[16] Tavares, S.S.M., Pardal, J.M., Lima, L.D., Bastos, I.N., Nascimento, A.M. and De Souza, J.A. (2007) Characterization of Microstructure, Chemical Composition, Corrosion Resistance and Toughness of a Multipass Weld Joint of Super Duplex Stainless Steel UNS S32750. Materials Characterization, 58, 610-616. https://doi.org/10.1016/j.matchar.2006.07.006

[17] Sandvik (2008) Sandvik Seamless Heat Exchanger Tubing. S-154-ENG. 03.2008. https://www.materials.sandvik/en/applications/ 
[18] ASTM A923 (2008) Standard Test Methods for Detecting Detrimental Intermetallic Phase in Duplex Austenitic/Ferritic Stainless Steels.

[19] ASTM E384 (2016) Standard Test Method for Microindentation Hardness of Materials.

[20] Roldão, A.M.B. (2010) Estudo do efeito do aporte térmico nas propriedades mecânicas e microestruturais do aço inoxidável duplex UNS S31803 em chapa grossa, soldada pelo processo GMAW.

[21] Hasselberg, T.P. (2009) A Feasibility Study of "Cold Metal Transfer"-Gas Metal Arc Welding (CMT-GMAW) Nickel Base Superalloy Inconel 718TM.

[22] Lippold, J.C. and Kotecki, D.J. (2005) Welding Metallurgy and Weldability of Stainless Steels. John Wiley \& Sons, Inc., Hoboken, NJ, 357 p.

[23] Tedeschi, P.A.L., Signorelli, R. and das Neves, M.D.M. (2010) Comparação da junta soldada pelo processo GTAW dos aços inoxidáveis AISI 316L e Super-Duplex UNS S32750 para trocadores de Calor Usados em Refinarias de Petróleo. XXXVI CONSOLDA-Congresso Nacional de Soldagem, Recife, PE, Brasil. 